\title{
PENGARUH PEMBERIAN LEAFLET TERHADAP PENGETAHUAN MAHASISWA UNIVERSITAS MULAWARMAN TERKAIT PENYAKIT HIV/AIDS

\author{
Asni $^{1, \dagger}$, Jaka Fadraersada ${ }^{1}$, Rolan Rusli ${ }^{1,2, \text { : }}$ \\ ${ }^{1}$ Laboratorium Penelitian dan Pengembangan Kefarmasian "Farmaka Tropis", \\ Fakultas Farmasi, Universitas Mulawarman, Samarinda, Indonesia \\ †Email: asnyarkyaa@gmail.com \\ ${ }^{2}$ Kelompok Bidang Ilmu Kimia Farmasi, Fakultas Farmasi, \\ Universitas Mulawarman, Samarinda, Indonesia \\ tEmail: rolan@farmasi.unmul.ac.id
}

\begin{abstract}
Currently, HIV/AIDS is a deadly disease and the cure have not found yet. The understanding of this diseases has a critical role to improve the prevention of this contagious disease. This research was carried out to obtain The Mulawarman University students level of knowledge about HIV/AIDS using quasi-experimental method with pre and post test questionnaire designs. Data was collected from August to September 2018 at Mulawarman University. The result shows there is an increase in student's post test value compared with their pre test which are in A Faculty (pre test 76,50\%; post test 87,26\%), B Faculty (pre test 89,40\%; post test 90,9\%), and C Faculty (pre test 77,9\%; post test $87,31 \%$ ). The research shows there is an increase of student's knowledge about HIVIAIDS after leaflet was given.
\end{abstract}

Keywords: HIV/AIDS, knowledge, leaflets, pre-test and post-test, quasi-experimental

\begin{abstract}
ABSTRAK
HIV/AIDS saat ini merupakan penyakit mematikan dan belum ditemukan obatnya. Pemahaman mengenai penyakit ini menjadi penting untuk meningkatkan pencegahan terhadap resiko tertular. Penelitian ini dilaksanakan untuk mengetahui tingkat pengetahuan Mahasiswa Universitas Mulawarman tentang HIV/AIDS dengan metode quasi ekperimental menggunakan kuisioner pre test and post test. Data diambil pada bulan Agustus hingga September2018 bertempat di Universitas Mulawarman. Hasil penelitian menunjukkan bahwa adanya peningkatan pengetahuan tentang HIV/AIDS setelah pemberian leaflet pada Fakultas A (pre test 76,50\%; post test 87,26\%), Fakultas B (pre test $89,40 \%$; post test $90,9 \%$ ), dan pada Fakultas C (pre test $77,9 \%$; post test $87,31 \%$ ). Dari penelitian ini diperoleh bahwa adanya peningkatan terhadap pengetahuan tentang HIV/AIDS sebelum dan sesusah diberikan leaflet.
\end{abstract}

Kata Kunci: HIV/AIDS, leaflet, pengetahuan, pre test and post test, quasi eksperimental 
DOI: https://doi.org/10.25026/mpc.v8i1.336

\section{PENDAHULUAN}

Terdapat beberapa masalah kesehatan di dunia yang hingga saat ini belum bisa terselesaikan. Salah satu permasalahan kesehatan yang sekarang menjadi Global Issues adalah HIV/AIDS. Human Immunodeficiency Virus (HIV) merupakan virus yang menyerang daya tahan tubuh manusia sehingga seseorang mudah terserap penyakit. Prevalensi HIV meningkat tahun 2002 dengan 31 juta orang dengan HIV/AIDS dan pada tahun 2012 meningkat menjadi 35,3 juta orang dengan HIV/AIDS (ODHA). Orang yang terinfeksi HIV,cepat atau lambat (2 sampai 10 tahun) akan menderita Acquired Immuno Deficiency Syndrome (AIDS) jika tidak berobat secara teratur. Sementara AIDS merupakan kumpulan gejala penyakit dengan karakteristik defisiensi imun yang berat dan merupakan manifestasi stadium akhir infeksi HIV (Noer, 2004).

Indonesia merupakan negara yang menempati urutan pertama dalam penularan HIV/AIDS di Asia Tenggara. Dari total populasi penduduk sebanyak 240 juta jiwa, Indonesia memiliki prevalensi HIV sebesar 0,24\% dengan estimasi ODHA 186.000, bahkan bisa mencapai 200.000. Pada tahun 20052015, kejadian kasus HIVsemakin meningkat, pada 10 tahun terakhir ditemukan ada 184.929 kasus HIV/AIDS yang dilaporkan (Kepmenkes, 2016).

HIV pertama kali dilaporkan terjadi pada tahun 1981 di Amerika Serikat. Pada awalnya tampak seperti penyakit yang hanya ditularkan oleh lakilaki homoseksual. Semakin lama penyebaran virus ini semakin meluas terutama kepada kelompok-kelompok masyarakat lain seperti pengguna obatobatan nakotika melalui jarum suntik dan para imigran Haiti. Apabila seseorang positif tertular HIV/AIDS merupakan persoalan besar karena sampai sekarang penyakit AIDS belum ada obatnya dan belum ada vaksin yang dapat mencegah serangan virus HIV. Hal tersebut didukung oleh Sarafino yang mengungkapkan bahwa sekarang tidak ada obat untuk menyembuhkan AIDS.

Mahasiswa merupakan salah satu kelompok yang berisiko terkena HIV/AIDS, hendaknya memiliki pengetahuan yang baik mengenai HIV/AIDS dan berupaya untuk mencegah penyakit yang mematikan ini. Namun, Pengetahuan yang baik belum tentu menghasilkan perilaku yang baik pula, perlu ada kesadaran dari dire sendiri untuk berupaya dalam mencegah penyakit tersebut.

Berdasarkan hal tersebut maka dilakukan penelitian di Universitas Mulawarman untuk melihat bagaimana pengetahuan mahasiswa mengenai penyebab, penularan, gejala, pengobatan, dan pencegahan penyakit HIV/AIDS.

\section{METODE PENELITIAN}

Penelitian yang dilakukan yaitu quasi eksperimental yang akan dianalisis secara deskriptif untuk mendapatkan hasil menggunakan kuisioner. Dalam pengambilan data dilakukan ssbanyak 2 kali pada setiap responden, dengan cara pre and post test. Pre test dilakukan dengan cara pengisian kuisioner sebelum pemberian leaflet dan post test dilakukan dengan cara pengisian kuisioner setelah memberikan leaflet kepada responden. Teknik pengambilan sampel dilakukan secara purposive sampling yaitu teknik penentuan sampel dengan pertimbangan tertentu, yaitu : dengan memperhatikan kriteria inklusi dan ekslusi. 
Populasi penelitian adalah semua mahasiswa Universitas Mulawarman. Sampel penelitian adalah mahasiswa Universitas Mulawarman yang memenuhi kriteria inklusi dan eksklusi.

Kriteria inklusi sampel adalah:

a. Mahasiswa aktif Universitas Mulawarman Angkatan 2016-2017

b. Fakultas Kesehatan (Farmasi) dan Non Kesehatan (Keguruan dan Ilmu Pendidikan dan Matematika dan Ilmu Pengetahuan Alam)

c. Usai 18-20 tahun

d. Bersedia menjadi responden, dibuktikan dengan tanda tangan pada surat pernyataan kesediaan

Kriteria Eksklusi pengambilan sampel untuk penelitian ini adalah Mahasiswa yang tidak dapat ditemui kembali.

\section{HASIL DAN PEMBAHASAN}

\section{Karakteristik responden}

Tabel 1. Jenis Kelamin

\begin{tabular}{c|c|c}
\hline Variabel & Jumlah & $\%$ \\
\hline Laki-laki & 27 & 44,27 \\
Perempuan & 34 & 55,73 \\
\hline Total & 61 & 100 \\
\hline
\end{tabular}

Tabel 2. Fakultas

\begin{tabular}{c|c|c}
\hline Variabel & Jumlah & $\%$ \\
\hline Fakultas A & 21 & 34,43 \\
Fakultas B & 16 & 26,23 \\
Fakultas C & 24 & 39,34 \\
\hline Total & 61 & 100 \\
\hline
\end{tabular}

Data yang dianalisis sejumlah 61 mahasiswa dengan usia 18-20 tahun yang terdiri dari 44,27\% laki-laki dan 55,73\% perempuan. Presentase responden perempuan lebih tinggi dibandingkan laki-laki dikarenakan proporsi jumlah mahasiswi lebih tinggi dibandingkan jumlah mahasiswa pada sebagian besar fakultas. Presentase responden yang berasal dari Fakultas A yaitu sebesar $34,43 \%$, Fakultas B sebesar 26,23\%, dan Fakultas C sebesar 39,34\%.

Tabel 3. Presentase tentang Pengertian HIV/AIDS

\begin{tabular}{c|c|c}
\hline Variabel & Pre test $(\%)$ & Post test $(\%)$ \\
\hline Fakultas A & 69,52 & 83,81 \\
Fakultas B & 88,75 & 83,75 \\
Fakultas C & 70,83 & 79,16 \\
\hline
\end{tabular}

Pada bagian aspek pengertian tentang HIV/AIDS didapatkan bahwa mayoritas responden Fakultas A memiliki pengetahuan yang meningkat tentang HIV/AIDS yaitu sebelum pemberian leaflet sebesar $69,52 \%$ dan sesudah pemberian leaflet $83,81 \%$, responden Fakultas $\mathrm{C}$ memiliki pengetahuan yang meningkat tentang HIV/AIDS yaitu sebelum pemberian leaflet sebesar $70,83 \%$ dan sesudah pemberian leaflet $79,16 \%$. Namun, pada responden Fakultas B didapatkan hasil mengalami penurunan setelah pemberian leaflet (sebelum $88,75 \%$, sesudah $83,75 \%$ ). Hal ini dapat terjadi disebabkan karena kurang seriusnya responden dalam membaca leaflet dan mengisi kuisioner yang diberikan. Pengertian ini penting diketahui untuk mencegah virus HIV masuk kedalam tubuh dan untuk meminimalisir virus HIV agar tidak berkembang menjadi AIDS. Menurut sensus penduduk tahun 2010 yang dilakukan oleh Badan Pusat Statistik (BPS), proporsi penduduk usia 15-19 tahun hampir mencapai 10 persen dari jumlah penduduk. Dengan populasi yang cukup besar, maka remaja diharapkan menjadi tumpuan dan tulang punggung dalam meneruskan pembangunan, oleh karena itu sangatlah penting untuk 
memberikan pemahaman dan pengetahuan yang benar dan tepat, termasuk informasi tentang HIV/AIDS.

Tabel 4. Presentase tentang Penyebab/Penularan HIV/AIDS

\begin{tabular}{c|c|c}
\hline Variabel & Pre test $(\%)$ & Post test $(\%)$ \\
\hline Fakultas A & 78,57 & 92,85 \\
Fakultas B & 96,09 & 94,53 \\
Fakultas C & 91,66 & 93,22 \\
\hline
\end{tabular}

Pada bagian aspek pengetahuan tentang penyebab/penularan HIV/AIDS hasil yang diperoleh dari Fakultas A dan Fakultas $\mathrm{C}$ mengalami peningkatan dengan presentase masing-masing yaitu Fakultas A sebesar 78,57\% sebelum pemberian leaflet dan 92,85\% sesudah pemberian leaflet, Fakultas $\mathrm{C}$ sebesar $91,66 \%$ sebelum pemberian leaflet dan 93,22\% setelah pemberian leaflet. Namun, pada responden Fakultas B didapatkan hasil yang mengalami penurunan setelah pemberian leaflet (sebelum 96,09\%, sesudah 94,53\%). Hal ini dapat terjadi dikarenakan peniliti tidak dapat menyediakan tempat khusus untuk responden membaca leaflet. Dalam proses belajar, tempat yang jauh dari kebisingan lebih baik dalam meningkatkan pengetahuan. Dikarenakan hal tersebut, peneliti tidak dapat mengontrol untuk tidak terjadinya komunikasi anatara responden. Dan juga dikarenakan adanya responden yang malas mengisi kuisioner dan membaca leaflet yang diberikan sehingga terdapat beberapa responden yang mengalami penurunan skor pengetahuan setelah diberikan media leaflet.
Tabel 5. Presentase tentang Gejala HIV/AIDS

\begin{tabular}{c|c|c}
\hline Variabel & Pre test $(\%)$ & Post test (\%) \\
\hline Fakultas A & 65,30 & 87,75 \\
Fakultas B & 81,25 & 89,28 \\
Fakultas C & 68,45 & 83,92 \\
\hline
\end{tabular}

Pada aspek pengetahuan tentang gejala HIV/AIDS hasil yang diperoleh dari Fakultas A, Fakultas B, serta Fakultas $\mathrm{C}$ mengalami peningkatan dengan presentase masing-masing yaitu Fakultas A sebesar $65,30 \%$ sebelum pemberian leaflet dan $87,75 \%$ sesudah pemberian leaflet, Fakultas $\mathrm{C}$ sebesar $68,45 \%$ sebelum pemberian leaflet dan $83,92 \%$ setelah pemberian leaflet, dan Fakultas B sebesar $81,25 \%$ sebelum pemberian leaflet dan $89,28 \%$ setelah pemberian leaflet.

Tabel 6. Presentase tentang Diagnosis HIV/AIDS

\begin{tabular}{c|c|c}
\hline Variabel & Pre test $(\%)$ & Post test $(\%)$ \\
\hline Fakultas A & 83,33 & 95,23 \\
Fakultas B & 87,5 & 87,5 \\
Fakultas C & 64,58 & 77,08 \\
\hline
\end{tabular}

Pada bagian aspek pengetahuan tentang penyebab/penularan HIV/AIDS hasil yang diperoleh dari Fakultas A dan Fakultas $\mathrm{C}$ mengalami peningkatan dengan presentase masing-masing yaitu Fakultas A sebesar 83,33\% sebelum pemberian leaflet dan 95,23\% sesudah pemberian leaflet, Fakultas B sebesar $64,58 \%$ sebelum pemberian leaflet dan $77,08 \%$ setelah pemberian leaflet, serta responden Fakultas $\mathrm{C}$ memberikan hasil yang tetap yaitu $87,5 \%$ sebelum dan setelah pemberian leaflet. 
Tabel 7. Presentase tentang Pencegahan HIV/AIDS

\begin{tabular}{c|c|c}
\hline Variabel & Pre test (\%) & Post test (\%) \\
\hline Fakultas A & 91,66 & 95,83 \\
Fakultas B & 89,35 & 91,20 \\
Fakultas C & 89,35 & 91,20 \\
\hline
\end{tabular}

Pada aspek pengetahuan tentang pencegahan HIV/AIDS hasil yang diperoleh dari Fakultas A, Fakultas B, serta Fakultas $\mathrm{C}$ mengalami peningkatan dengan presentase masing-masing yaitu Fakultas A sebesar 91,66\% sebelum pemberian leaflet dan $95,83 \%$ sesudah pemberian leaflet, Fakultas $\mathrm{C}$ sebesar $76,82 \%$ sebelum pemberian leaflet dan $84,44 \%$ setelah pemberian leaflet, dan Fakultas B sebesar 89,35\% sebelum pemberian leaflet dan $91,20 \%$ setelah pemberian leaflet.

Tabel 8. Presentase tentang Pengobatan HIV/AIDS

\begin{tabular}{c|c|c}
\hline Variabel & Pre test $(\%)$ & Post test $(\%)$ \\
\hline Fakultas A & 76,82 & 84,44 \\
Fakultas B & 88,75 & 89,58 \\
Fakultas C & 72,22 & 87,5 \\
\hline
\end{tabular}

Pada aspek pengetahuan tentang pengobatan HIV/AIDS hasil yang diperoleh dari Fakultas A, Fakultas B, serta Fakultas $\mathrm{C}$ mengalami peningkatan dengan presentase masing-masing yaitu Fakultas A sebesar 76,82\% sebelum pemberian leaflet dan $84,44 \%$ sesudah pemberian leaflet, Fakultas $\mathrm{C}$ sebesar $72,22 \%$ sebelum pemberian leaflet dan $87,5 \%$ setelah pemberian leaflet, dan Fakultas B sebesar $88,75 \%$ sebelum pemberian leaflet dan $89,58 \%$ setelah pemberian leaflet.

Pengetahuan yang benar dan tepat tentang HIV/AIDS yang meliputi pengertian, penyebab/penularan, gejala, diagnosis, pencegahan, dan pengobatan menjadi salah satu poin penting dalam upaya menghindari penularan HIV, walaupun pengetahuan yang baik yang dimiliki oleh reponden ternyata tidak menjamin bahwa responden tidak melakukan kegiatan yang berisiko terinfeksi HIV. Dalam Notoadmojo, (2003), menyebutkan bahwa pengetahuan yang berbeda-beda antara item soal dipengaruhi oleh instruksi verbal. Intruksi verbal merupakan penerimaan informasi verbal seperti melihat, mendengar melalui alat komunikasi sepertir radio, televisi, internet dan petugas kesehatan yang mengakibatkan responden memiliki tingkat pengetahuan yang berbeda-beda (McManus \& Dhar,2008). Hal ini sesuai dengan teori dimana tingkat pengetahuan akan berpengaruh terhadap prilaku responden dalam pencegahan HIV/AIDS. Tingkat pengetahuan merupakan domain untuk seseornag melakukan tindakan. Seseorang dianggap memahami ditunjukan melalui dan dapat berarti responden mampu membaca kondisi bahasa HIV/AIDS dan cara penularannya (Shiferaw et al., 2011), sehingga dapat melakukan pencegahan.

Perbedaan tingkat pengetahuan responden berdasarkan kelompok fakultas dapat terjadi dikarenakan setiap fakultas tentunya mempelajari hal yang berbeda sesuai dengan bidangnya masing-masing (bidang Kesehatan dan non kesehatan). Pada Fakultas A yang bekerja dibidang kesehatan, seharusnya mahasiswa Fakultas A memiliki tingkat pengetahuan yang lebih baik dibandingkan dengan fakultas lainnya yang bukan bekerja dibidang kesehatan, sebab mahasiswa Fakultas A telah dibekali ilmu pengetahuan dan pemahaman mengenai berbagai penyakit seperti HIV/AIDS. Akan tetapi bukan berarti mahasiswa dari Fakultas lainnya tidak memiliki pengetahuan yang lebih baik, karena berbagai informasi mengenai HIV/AIDS dapat diaskes sendiri melalui internet, buku, seminar, dll. 


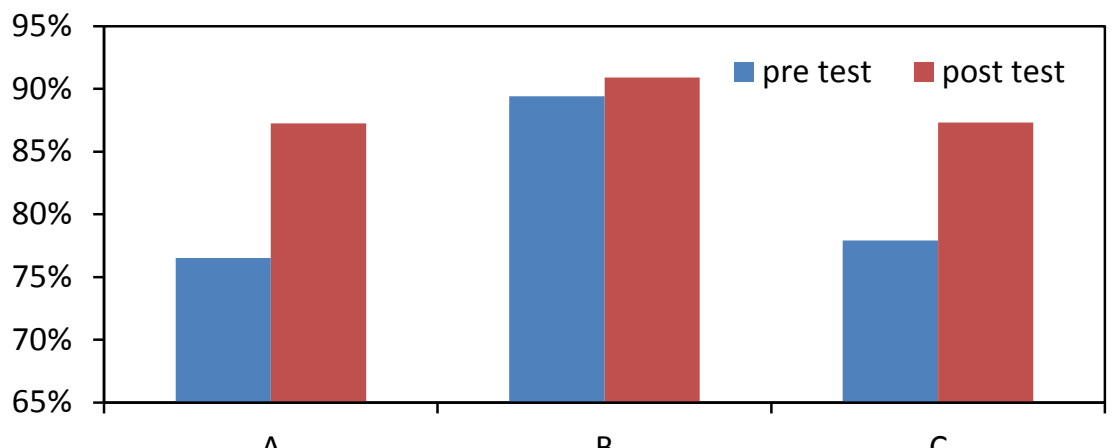

A

C

Gambar 1. Pengetahuan Mahasiswa tentang Penyakit HIV/AIDS

Tabel 9. Presentase Perbandingan Peningkatan Jawaban Berdasarkan Jenis Kelamin

\begin{tabular}{c|c|c}
\hline Variabel & Pre test $(\%)$ & Post test $(\%)$ \\
\hline Laki-laki & 84,86 & 90,74 \\
Perempuan & 84,88 & 91,5 \\
\hline
\end{tabular}

Faktor yang memungkinkan adanya perbedaan pengetahuan antara responden laki-laki dan perempuan adalah responden perempuan biasanya cenderung lebih peduli terhadap dirinya sehingga responden perempuan lebih giat dalam menggali informasi terkait kesehatannya sehingga pengetahuannya lebih meningkat.

Pengetahuan merupakan salah satu faktor yang mempengaruhi sikap dan perilaku seseorang. Menurut Lawrence Green dan Marshall Kreuter dalam Sciavo (2007) bahwa pengetahuan seseorang merupakan salah satu faktor predisposisi yang dapat mempengaruhi perubahan perilaku seseorang. Pengetahuan yang benar tentang HIV/AIDS diharapkan dapat menghindari perilaku berisiko HIV/AIDS.

Dapat disimpulkan bahwa tingkat pengetahuan responden tidak semuanya dipengaruhi oleh latar belakang pendidikannya (Fakultasnya). Pengetahuan yang dimiliki oleh responden juga dapat diperoleh dari sumber lain misalnya internet, buku, seminar, dll.

\section{KESIMPULAN}

Pengetahuan

mengenai HIV/AIDS pada mahasiswa Universitas Mulawarman tergolong baik. Mayoritas responden memiliki pengetahuan tentang HIV/AIDS dan upaya pencegahan dalam kategori tinggi meliputi pengertian, penyebab/penularan, gejala, diagnosis, pencegahan dan pengobatan (terapi) HIV\&AIDS. Hasil temuan ini menunjukkan masih banyak kegiatan pencegahan yang perlu dilakukan terutama tentang perlunya peningkatan pengetahuan melalui komunikasi, informasi dan edukasi tentang faktor pencegahan HIV/AIDS.

\section{DAFTAR PUSTAKA}

Aristo, Parut, Ansemus. 2016. Hubungan Pengetahuan Tentang HIV/AIDS Dengan Stigma Terhadap ODHA Pada Siswa Kelas Xi SMK VI Surabaya. Jurnal Ners LENTERA, Vol. 4, No. 2. 
Departemen Kesehatan RI, 2006, Situasi HIV/AIDS di Indonesia tahun 1987-2006, Depkes RI, Jakarta.

H. M. S. Noer. 2004. Buku Ajar Ilmu Dalam Jilid I Edisi Ketiga. Balai Penerbilt FKUI. Jakarta

Kepmenkes. 2016. Informasi Pusat Data dan Informasi Kementrian Kesehatan RI.

Komisi Penanggulangan AIDS Nasional. 2011. Rangkuman Eksekutif Upaya Penanggulangan HIV dan AIDS di Indonesia 2006-2011: Laporan 5 Tahun Pelaksanaan Peraturan Presiden No.75/2006 tentang Komisi Penanggulangan AIDS Nasional.

Komisi Penanggulangan AIDS Nasional. 2003. Strategi Nasional Penanggulangan HIV/AIDS 2003-2007.

McManus, A., \& Dhar, L. (2008). Study of knowledge, perception and attitude of adolescent girls towards STIs/HIV, safer sex and sex education: (A cross sectional survey of urban adolescent school girls in South Delhi, India). BMC Women's Health, 8, 12.

Notoadmojo, Soekidjo. 2003. Pendidikan dan Perilaku Kesehatan. PT Rineka Cipta: Jakarta

Nurachmah, Elly., Mustikasari. 2009. Faktor Pencegahan HIV/AIDS Akibat Perilaku Berisiko Tertular Pada Siswa SLTP. Makara Kesehatan, Vol. 13, No. 2.

Rahayu Inggit., Rismawanti Venny., Jaelani Khodir Abdul. 2017.
Hubungan Tingkat Pengetahuan

Tentang HIV/AIDS dengan

Perilaku Seksual Pranikah

Pelajar.Journal Endurance, Vol.2, No.2.

Rokhmah Dewi, Khoiron. 2013. Pengetahuan Dan Sikap ODHA (Orang Dengan Hiv Dan Aids) Tentang HIV Dan AIDS Dan Pencegahannya. Jurnal IKESMA, Vol. 9, No. 2.

Schiavo, Renata. Health Communication: from theory to practice, San Fransisco: John Wiley \& Sons. Inc. 2007.

Shiferaw, Y., Alemu, A., Girma, A., Getahun, A., Kassa, A., Gashaw, A., Gelaw, B. 2011. Assessment of knowledge, attitude and risk behaviors towards HIV/AIDS and other sexual transmitted infection among preparatory students of Gondar town, north west Ethiopia. BMC Research Notes, 4, 505.

Setiawati, Novi. 2014. Pengetahuan dan Perilaku Mahasiswa Universitas Surabaya Terkait Upaya Pencegahan HIV/AIDS. Jurnal Ilmiah Mahasiswa Universitas Surabaya. Vol. 3. No. 1.

Sudikno, Simanungkalit Bona, Siswanto. 2011. Pengetahuan HIV Dan AIDS Pada Remaja Di Indonesia (Analisis Data Riskesdas 2010). Jurnal Kesehatan Reproduksi Vol. 1 No. 3. 